\title{
Application of the Technology Life Cycle and S-Curves to the "Brain Drain" Area of Knowledge
}

\author{
Andres Escobar ${ }^{1 *}$ and Jhon W. Zartha ${ }^{2}$ \\ 'Universidad Pontificia Bolivariana, Facultad de Negocios Internacionales, Escuela de Economia, \\ Administracion y Negocios, Medellin, Colombia; andres.escobarur@upb.edu.co \\ Universidad Pontificia Bolivariana, Facultad de Ingenieria Agroindustrial, Escuela de Ingenierias, Medellin, \\ jhon.zartha@upb.edu.co
}

\begin{abstract}
Objective: The purpose of this paper is to apply an S-curve methodology to the area of knowledge of brain drain. Methods and Analysis: Thirteen non-linear models were applied through the statistical software SigmaPlot (online version) in an accumulated data series of articles obtained in the online data base SCOPUS. Afterwards, the inflection point was calculated and such was validated through " $\mathrm{p}$ " and " $\mathrm{t}$ " values. In addition, the Durbin Watson and adjusted $\mathrm{R}$ square values were also calculated. Findings: After the application of the thirteen non-linear models: sigmoidal 3, 4 and 5 parameters, logistic 3 and 4 parameters, Weibull 4 and 5 parameters, Gompertz 3 and 4 parameters, Hill 3 and 4 parameters and Chapman 4 and 5 parameters, the models with the best fit were sigmoidal and logistic, which gave an inflection point in the year 2023. These models were validated through the following ranges: T value greater than 2 or less than-2, P value less than 0.005 . Given that the inflection point occurs in the future, this presents a great opportunity for academics and researchers who focus the topic of brain drain to publish given the high dynamism in online databases like SCOPUS. Novelty: The S-curve methodology and technology life cycle (usually executed in subjects related to technology) was implemented in this article with the innovative approach to apply it to a specific area of knowledge.
\end{abstract}

Keywords: Brain Drain, Curves, S Inflection Points, Technology Life Cycle

\section{Introduction}

This article comprehends the study of $S$ curves regarding the brain drain phenomenon. The methodology used provides an element of added value for decision making related to the dynamism of publications on the subject based on what has been researched by other authors regarding the technology life cycle $\frac{1,2}{2}$. This is important since academics and researchers related to the study of brain drain can find a tool for decision making related to the possibility of validating their interest in the generation of projects, publication of papers and new lines of research, amongst other aspects.

The main objectives of the study presented in the paper are: to search for articles on the Scopus database regarding the topic of brain drain to apply "S" curves in the selected topic and calculate the inflection point.

\subsection{Theoretical Framework}

The "brain drain" phenomenon has a long history dating back to 1963, when the Royal Society defined the "brain drain" of the exodus of British scientists to the United States, seriously endangering the British economy, and it was from this situation that this term came to be commonly used to describe the emigration of scholars and professionals from third world countries or former colonies ${ }^{3}$.

Recently, keeping in mind the epistemological essence of the phenomenon, brain drain migration has been mutating to the point where, according to experts like

${ }^{*}$ Author for correspondence 
Grubel ${ }^{4}$ "it is the process of abandonment of a country in favor of another by professionals or people with a high level of education, generally following an offer of better pay or living conditions), as well as improved conditions for conducting one's professional activities".

Understanding that both definitions talk about the movement of human capital and a potential loss of specialized knowledge, the complexity of the singularity has been a topic of research and study by several institutions of higher education, companies, and governments, who now have determined that such adjusts daily to the high dynamism of globalization ${ }^{5}$.

When such migration is under the umbrella of a macro phenomenon such as globalization, its impact and measurement become a difficult task, even for institutions that count with the appropriate resources (financial and human $)^{\frac{5}{}}$ obtained information from both the OECD and the UNESCO stating that:

“(...) testing the brain exchange hypothesis becomes difficult since there are no systematic statistics of inward and outward flows for many countries. In addition, countries use different criteria to classify migrants and do not always collect data on specializations. The strong iteration is therefore still impossible to verify at a systematic and global level" (Milo et al, 2012 pg.16).

As any measurable phenomenon or area knowledge, the application of S-curves, in the last years, has been extended to understand the behavior and the strategies that can be implemented in each one of the phases of technology, innovation or life cycle of a specific are of knowledge. This is evidenced by the studies of $\frac{2,6}{}$ who have deepened in analysis of the state of technology: emergent, incoming, key, and mature or in decline; and the possible strategies to follow: monitoring, selective investment or overinvestment. The research on the behavior of technology in each phase: initial, early growth, late growth and maturity are added to these studies ${ }^{1}$. The aforementioned can be observed graphically in Figure $1^{\frac{7-9}{2}}$ present specific cases on the technology life cycle, curves for diffusing technological innovations and adopting them through $S$ curves $^{10}$.

On the applications of $S$ curves in innovations, these have associated a series of market, trade and technological uncertainties, which are increased with the need for information or knowledge about the variables involved in the process of launching a new product or improvement

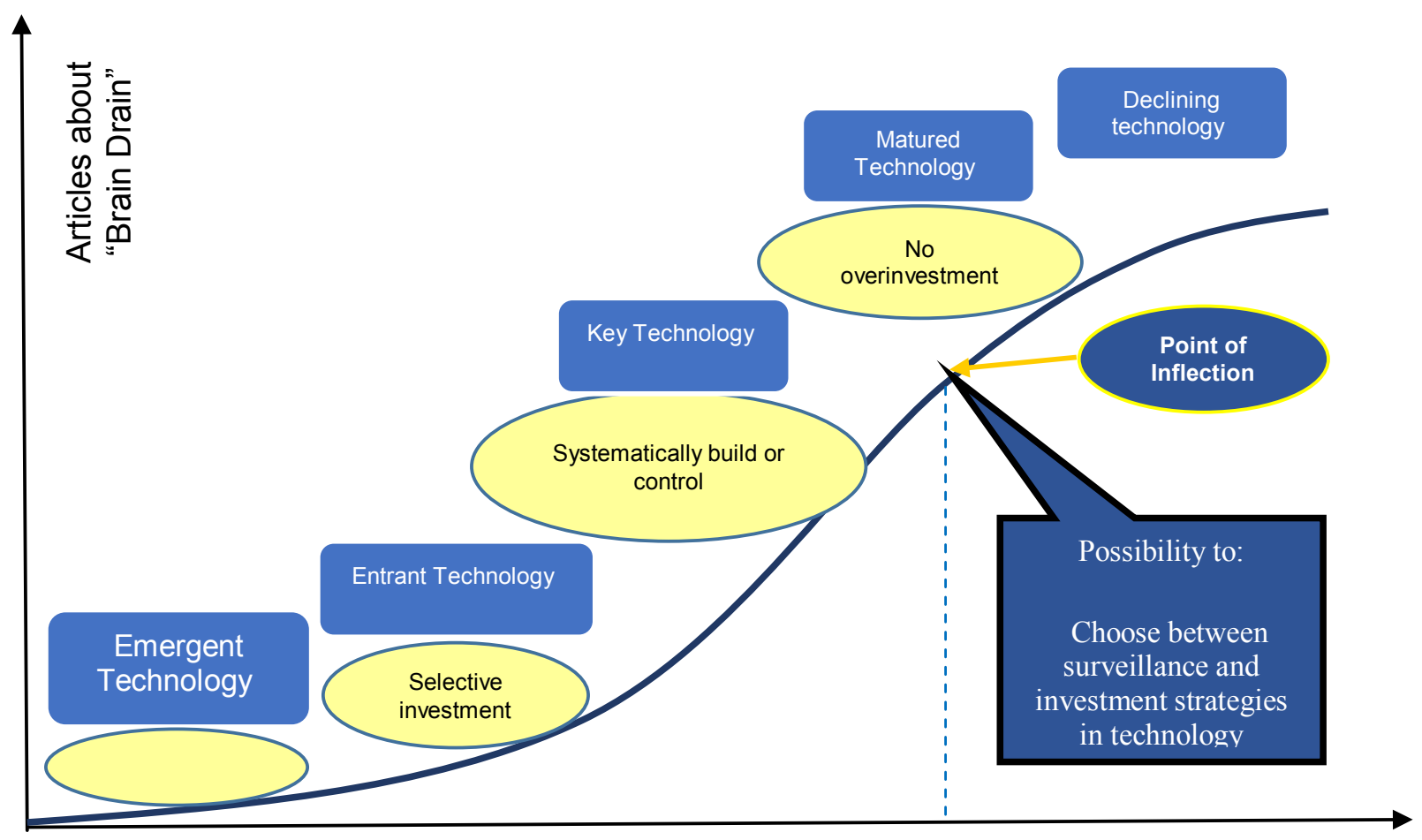

Source: Adapted from Ortiz \& Pedroza 2 , Perez $\stackrel{1,3}{ }$

Figure 1. Phases of the technology life cycle and possible monitoring and investment strategies. 
of an existing one $\mathrm{e}^{\frac{11-14}{4}}$. Likewise, technological uncertainty refers to the need for additional knowledge about the components and how the methods and techniques are related for the new product to work properly ${ }^{10}$. According to ${ }^{10}$ : "These uncertainties can be reduced through the study of technological regularities, market regularities and the use of appropriate innovation strategies. The most appropriate way to analyze technological regularities is through S-curves, so the company can analyze the performance of innovation over time. Similarly, market regularities can be studied by means of S-curves".

It is relevant to highlight that $\mathrm{S}$ curve models serve as a possibility to comprehend dynamics of change, to expose trends, causes, probabilities and possibilities in social, political, economic and technological surveillance.

Regarding bibliographical application (such as the one intended in this article $\frac{15}{}$, states that the practice of citation analysis has become a fundamental part of the construction of scientific knowledge. In the early invention stage of cite indexation, that was initially oriented to the recovery of information, proposed the use of databases to reconstruct the history of scientific ideas.

Finally, Price ${ }^{16}$ exposes that progress regarding S-curve stages tends to be slow at the beginning, and then through a trial and error process, the field starts to become systemized. In the growth stage, the increase is fast and sustained. Finally, when the technology (in this case an academic field or an area of knowledge), an upper limit is reached and development becomes slow again. When technology is understood to be "matured", such begins to decline and a new one that offers users benefits that are more attractive substitutes it. In relevance with the aforementioned, it is possible to guide bibliometric analysis with the objective of understanding future areas of importance for research and academic knowledge $e^{17}$.

\section{Methodology}

The methodology was developed in the following phases:

\subsection{Phase 1. Selection of Accumulated Data}

An equation or search strategy was established for articles in the database SCOPUS. From the documents obtained, a time series was organized with the accumulated articles.

\subsection{Phase 2. Application of S-curve Models}

The accumulated data obtained in the articles was entered in Sigma plot software (online version) and the 13 preloaded models in the program were applied: sigmoidal 3 , 4 and 5 parameters, logistic 3 and 4 parameters, Weibull 4 and 5 parameters, Gompertz 3 and 4 parameters, Hill 3 and 4 parameters and Chapman 4 and 5 parameters. In each of these models, the inflection point was calculated through non-linear regression.

\subsection{Phase 3. Selection of Model with the Best Fit}

With the results obtained in each of the thirteen models of the software, the inflection point and all the parameters of each model were validated with the $T$ and $P$ values. Those models (with all their parameters) with values of $-2\langle\mathrm{~T}\rangle$ 2 and $\mathrm{P}<0.005$ were taken as valid, that is, models with greater fit. Other indicators such as adjusted R2 value and Durbin Watson were also taken into account.

\subsection{Phase 4. Decision-Making}

Based on the results of the calculation of the inflection point in the models with the best fit, contributions were

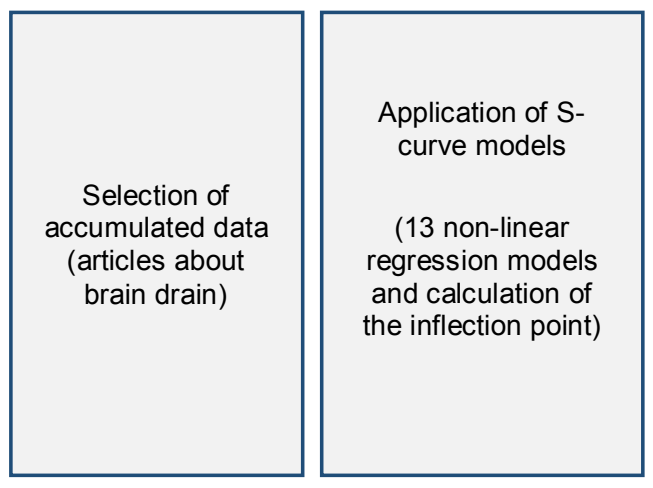

Source: Self-elaborated

Figure 2. Phases of the methodology.
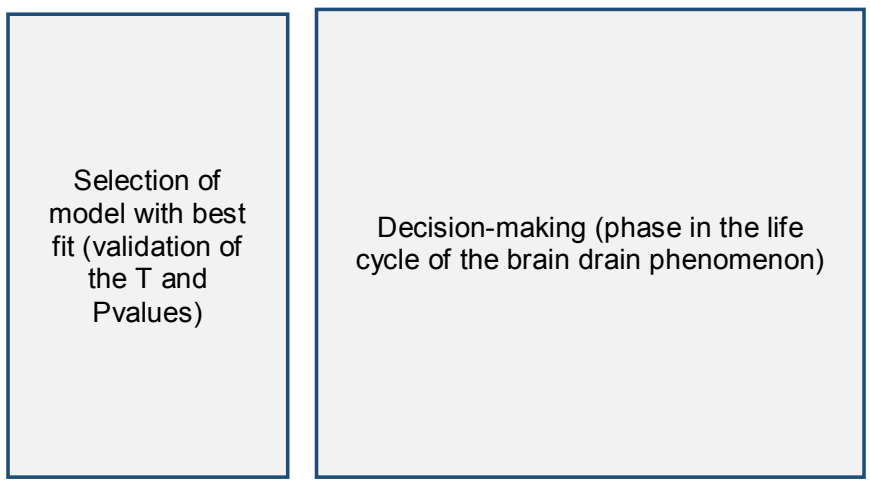
made according to the current phase in the life cycle of the brain drain phenomenon. The summary of methodology is explained in Figure 2.

Table 1. Time series of accumulated articles of brain drain

\begin{tabular}{|c|c|c|}
\hline Years & $\begin{array}{c}\text { Number Of } \\
\text { Articles Per } \\
\text { Year }\end{array}$ & $\begin{array}{c}\text { Accumulated } \\
\text { Series }\end{array}$ \\
\hline 1964 & 2 & 2 \\
\hline 1965 & 2 & 4 \\
\hline 1966 & 6 & 10 \\
\hline 1967 & 23 & 33 \\
\hline 1968 & 9 & 42 \\
\hline 1969 & 5 & 47 \\
\hline 1970 & 10 & 57 \\
\hline 1971 & 12 & 69 \\
\hline 1972 & 8 & 77 \\
\hline 1973 & 7 & 84 \\
\hline 1974 & 12 & 96 \\
\hline 1975 & 12 & 108 \\
\hline 1976 & 2 & 110 \\
\hline 1977 & 7 & 117 \\
\hline 1978 & 5 & 122 \\
\hline 1979 & 5 & 127 \\
\hline 1980 & 11 & 138 \\
\hline 1981 & 7 & 145 \\
\hline 1982 & 2 & 147 \\
\hline 1983 & 6 & 153 \\
\hline 1984 & 8 & 161 \\
\hline 1985 & 9 & 170 \\
\hline 1986 & 12 & 182 \\
\hline 1987 & 13 & 195 \\
\hline 1988 & 15 & 210 \\
\hline 1989 & 8 & 218 \\
\hline 1990 & 16 & 234 \\
\hline 1991 & 10 & 244 \\
\hline 1992 & 30 & 274 \\
\hline
\end{tabular}

\begin{tabular}{|c|c|c|}
\hline 1993 & 19 & 293 \\
\hline 1994 & 13 & 306 \\
\hline 1995 & 11 & 317 \\
\hline 1996 & 7 & 324 \\
\hline 1997 & 17 & 341 \\
\hline 1998 & 13 & 354 \\
\hline 1999 & 9 & 363 \\
\hline 2000 & 21 & 384 \\
\hline 2001 & 32 & 416 \\
\hline 2002 & 28 & 444 \\
\hline 2003 & 38 & 482 \\
\hline 2004 & 59 & 541 \\
\hline 2005 & 71 & 612 \\
\hline 2006 & 81 & 693 \\
\hline 2007 & 92 & 785 \\
\hline 2008 & 100 & 885 \\
\hline 2009 & 110 & 995 \\
\hline 2010 & 92 & 1087 \\
\hline 2011 & 119 & 1206 \\
\hline 2012 & 107 & 1313 \\
\hline 2013 & 121 & 1434 \\
\hline 2014 & 120 & 1554 \\
\hline 2015 & 115 & 1669 \\
\hline 2016 & 88 & 1757 \\
\hline 2017 & 28 & 1785 \\
\hline
\end{tabular}

\section{Results}

For the analysis of the life cycle through S-curves based on scientific articles, the following search equation wasused:

\subsection{Title-ABS-Key ("Brain Drain")}

The equation yielded the time series shown below:

The results regarding the accumulated articles are represented in Table 1.

The accumulated data series was uploaded to the Sigma plot software, where the 13 non-linear regression models were applied and their respective inflection points 
Table 2. Results on the application of the 13 non-linear regression models in accumulated articles about brain drain

\begin{tabular}{|c|c|c|c|c|c|c|}
\hline \multirow{2}{*}{$\begin{array}{l}\text { Articles } \\
\text { Validity }\end{array}$} & \multicolumn{6}{|c|}{ Brain Drain } \\
\hline & Model & $\begin{array}{l}\text { Inflexion } \\
\text { Point }\end{array}$ & $\begin{array}{l}\text { Adjusted } \\
\text { R2 }\end{array}$ & t Value & p Value & $\begin{array}{l}\text { Durbin } \\
\text { Watson }\end{array}$ \\
\hline No & Sigmoidal 3 & 2166 & 0.9886 & $\begin{array}{c}\text { Doesn't } \\
\text { meet the } \\
\text { value }\end{array}$ & $\begin{array}{l}\text { Doesn't } \\
\text { meet the } \\
\text { value }\end{array}$ & 0.1847 \\
\hline Yes & Sigmoidal 4 & 2023 & 0.9914 & $\begin{array}{c}\text { Meets the } \\
\text { value }\end{array}$ & $\begin{array}{c}\text { Meets the } \\
\text { value }\end{array}$ & 0.1949 \\
\hline No & Sigmoidal 5 & 2015 & 0.9943 & $\begin{array}{c}\text { Doesn't } \\
\text { meet the } \\
\text { value }\end{array}$ & $\begin{array}{c}\text { Doesn't } \\
\text { meet the } \\
\text { value }\end{array}$ & 0.0827 \\
\hline No & Logístico 3 & 2158 & 0.9885 & $\begin{array}{c}\text { Doesn't } \\
\text { meet the } \\
\text { value }\end{array}$ & $\begin{array}{c}\text { Doesn't } \\
\text { meet the } \\
\text { value }\end{array}$ & 0.1801 \\
\hline Yes & Logístico 4 & 2023 & 0.9913 & $\begin{array}{c}\text { Meets the } \\
\text { value }\end{array}$ & $\begin{array}{c}\text { Meets the } \\
\text { value }\end{array}$ & 0.195 \\
\hline No & Weibull 4 & 2124 & 0.9884 & $\begin{array}{c}\text { Doesn't } \\
\text { meet the } \\
\text { value }\end{array}$ & $\begin{array}{c}\text { Doesn't } \\
\text { meet the } \\
\text { value }\end{array}$ & 0.1843 \\
\hline No & Weibull 5 & 2014 & 0.9915 & $\begin{array}{c}\text { Doesn't } \\
\text { meet the } \\
\text { value }\end{array}$ & $\begin{array}{c}\text { Doesn't } \\
\text { meet the } \\
\text { value }\end{array}$ & 0.1685 \\
\hline No & Gompertz 3 & The model & d not adju & $t$ given that & needed mo & nteractions \\
\hline No & Gompertz 4 & The model & id not adju & $t$ given that & needed mo & nteractions \\
\hline No & Hill 3 & 2080 & 0.8324 & $\begin{array}{c}\text { Doesn't } \\
\text { meet the } \\
\text { value }\end{array}$ & $\begin{array}{c}\text { Doesn't } \\
\text { meet the } \\
\text { value }\end{array}$ & 0.022 \\
\hline No & Hill 4 & 2071 & 0.9202 & $\begin{array}{c}\text { Doesn't } \\
\text { meet the } \\
\text { value }\end{array}$ & $\begin{array}{c}\text { Doesn't } \\
\text { meet the } \\
\text { value }\end{array}$ & 0.0331 \\
\hline No & Cahpman 3 & & 0.9871 & $\begin{array}{c}\text { Doesn't } \\
\text { meet the } \\
\text { value }\end{array}$ & $\begin{array}{c}\text { Doesn't } \\
\text { meet the } \\
\text { value }\end{array}$ & 0.1486 \\
\hline No & Cahpman 4 & & 0.9906 & $\begin{array}{c}\text { Doesn't } \\
\text { meet the } \\
\text { value }\end{array}$ & $\begin{array}{c}\text { Doesn't } \\
\text { meet the } \\
\text { value }\end{array}$ & 0.2455 \\
\hline
\end{tabular}


where calculated. The results are shown in the following Table 2.

According to the data obtained in the non-linear regression from the Sigma plot software, the models that met the requirements to be valid ( $\mathrm{T}$ value greater than 2 or less than $-2, \mathrm{P}$ value less than 0.005 ) were the sigmoidal 4 and Logistic 4 . This coincides with other studies made ${ }^{18}$ where the sigmoidal models obtained a better fit (for three technologies in fish by-products); logistic 4 parameters (financial and telecommunications sector) and sigmoidal 4 parameters (financial sector, product housing credit).

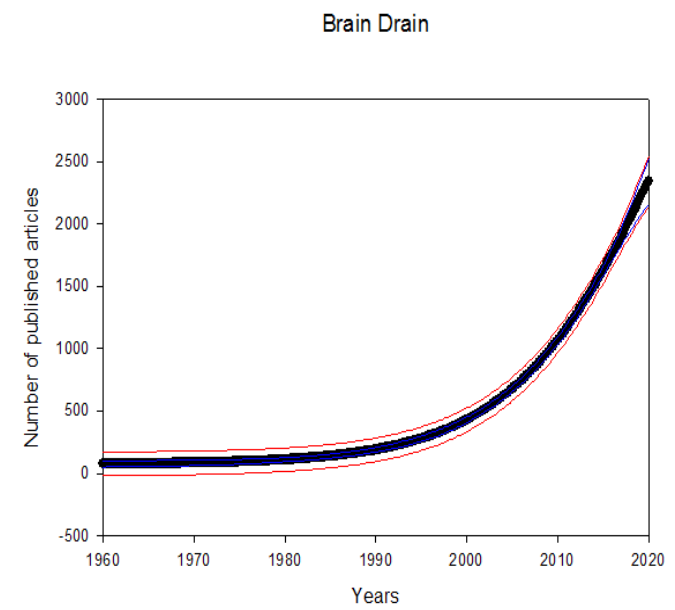

Source: Self-Elaborated

Figure 3. (Logistics 4 Parameters).

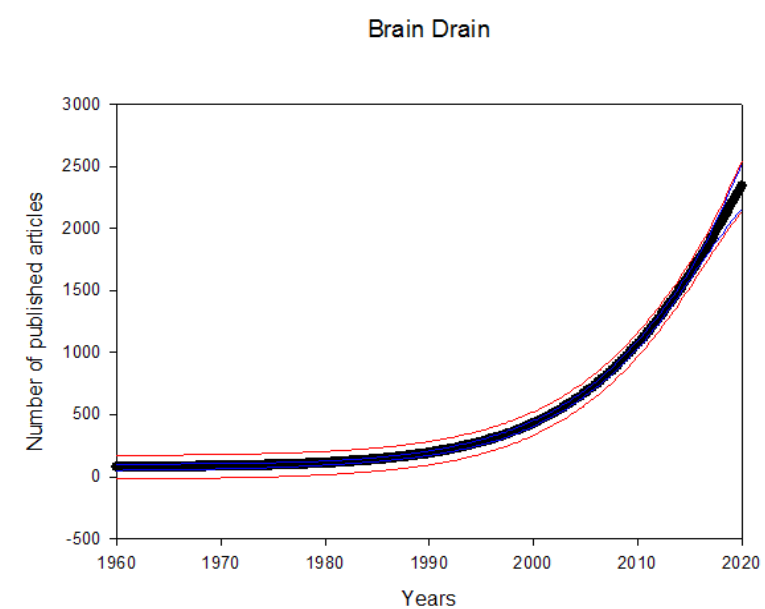

Source: Self-Elaborated

Figure 4. (Sigmoidal 4 Parameters).

In other studies on tourism-related issues ${ }^{19}$, the business diagnostic tool in this article's data series also obtained sigmoidal and logistic winning models. In addition, in the product lifecycle subject, four models had a better fit; amongst them were the sigmoidal and logistic models, which also coincide with the results obtained in this research.

According to the value of the inflection point, year 2023 , it can be established that the rhythm of scientific production of articles presents a high degree of dynamism, which has allowed it not to occur at an inflection

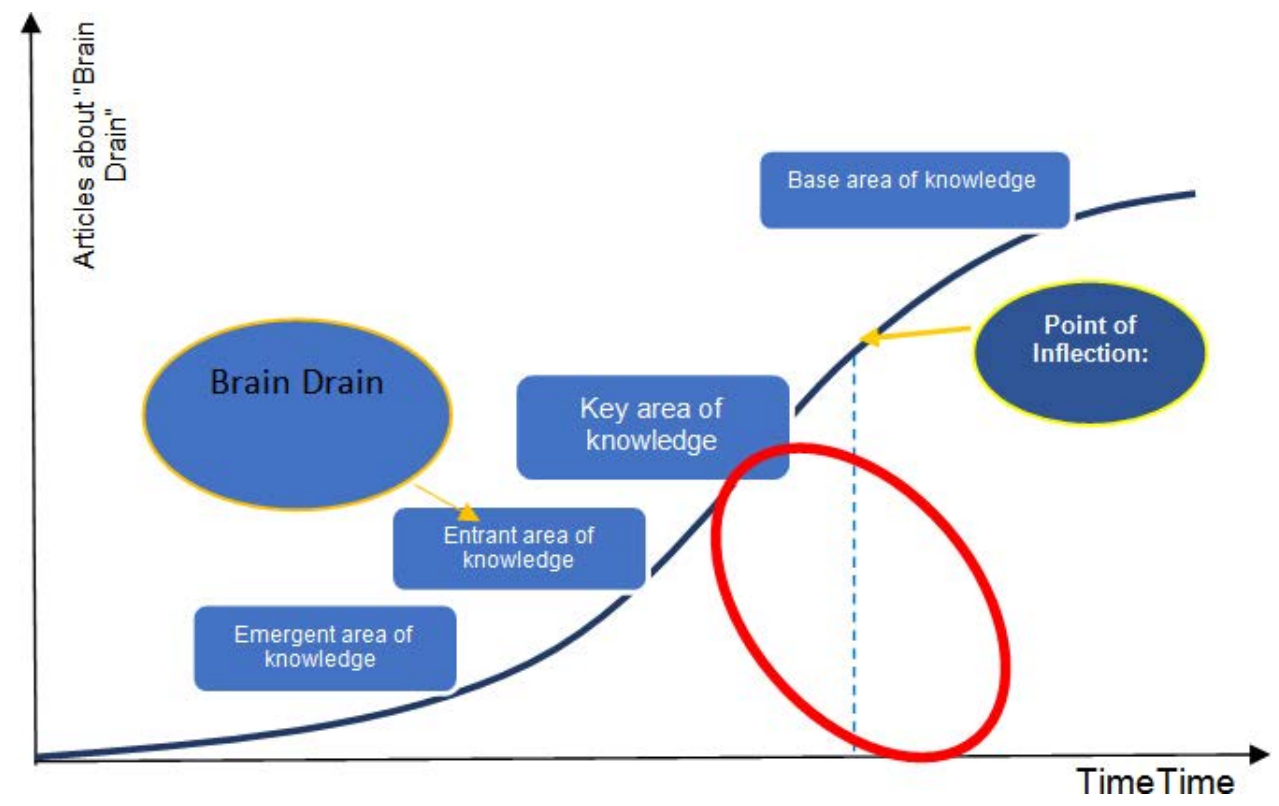

Source: Self-elaborated

Figure 5. Position of the brain drain area of knowledge in the S-curve. 
point before the year 2017. This presents a great opportunity for academics and researchers who focus the topic of brain drain since The rate of magazine publication in Scopus is still high. Figures 3 and 4 show the results obtained in accumulated articles through the application of the non-linear models Logistics and Sigmoidal.

Based on the different classifications of a technology according to Ortiz \&Pedroza ${ }^{2}$, understanding the existent correlation between technology and knowledge and that it is possible to guide a bibliometric analysis comprehending future areas of importance for research and academic knowledge ${ }^{\frac{18}{8}}$, Figure 5 aims to demonstrate that a respective area of knowledge, in this case brain drain, can be found in the initial phases before the inflection point of the life cycle (emergent, entrant and key). After the inflection point, we propose that an area of knowledge is not categorized as matured or declined but rather as a base area of knowledge.

For the brain drain phenomenon, it can be observed that, in terms of the number of articles published per year, it was identified that the highest number of publications was presented during the year 2011, with 131 documents and then in 2013, with a total of 130 Documents. This shows a growing trend in terms of the magnitude of publications per year.

The authors who have published most articles on brain drain have been Docquier, Frederick, Rapoport, $\mathrm{H}$. Hugo, G. Kapur and D. Lien, D.

Finally, Table 3 shows the countries that present the most publications regarding brain drain.

Table 3. Number of publication per country

\begin{tabular}{|l|l|}
\hline United States & $\mathbf{4 7 9}$ \\
\hline United Kingdom & 188 \\
\hline Germany & 91 \\
\hline Canada & 75 \\
\hline France & 71 \\
\hline Australia & 66 \\
\hline South Africa & 66 \\
\hline China & 59 \\
\hline Belgium & 56 \\
\hline Italy & 54 \\
\hline
\end{tabular}

Source: Self-elaborated

At a graphic level, Figure 6 shows the percentages of publications per country.
The point of inflection obtained in the topic of brain drain was the year 2023, which reflects a high dynamism regarding the production of articles and represents a great opportunity for academics and researchers related to this area of knowledge, with a possible research opportunity forcourses taught in undergraduate and graduate programs dealing with this topic (business, economic, political science and sociology, amongst others).

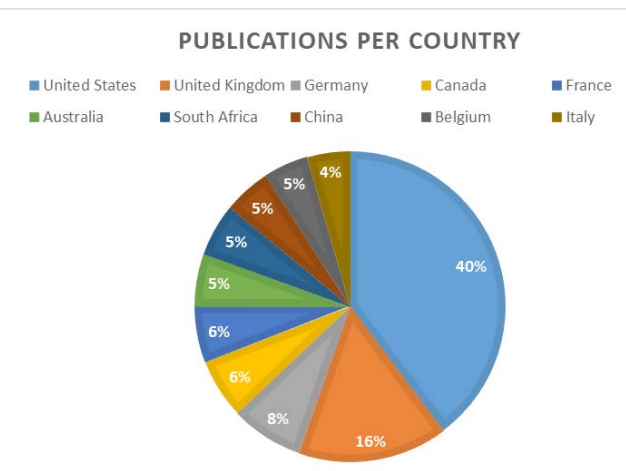

Source: Self-elaborated

Figure 6. Percentage of publications per country.

Within the thirteen nonlinear regression models applied, the models with the best fit for the brain drain theme were Sigmoidal and logistic. This coincides with results obtained in other subjects in the financial sector, telecommunications, product-housing credit and in subjects of agro-industry. New applications of these models are necessary with search equations on the same subject or related areas of knowledge in order to generate definitive information on the best-fit models on the topic studied in this paper.

The countries with the highest production of articles in brain drain are The United States, The United Kingdom, Germany, Canada, France, Australia, and South Africa, all with a production rate above 60 articles in the past five years. The years with the highest percentage of publication were 2011 and 2013. Not one Latin American country was present in the ranking within the 10 countries with highest publication rates, meaning that in this region article publication is low, representing an opportunity for academics that wish to research and publish on this topic.

S-curves have had multiple uses in technology and innovation both qualitatively and quantitatively, given the close relationship between these two phenomena with fields or areas of knowledge. It is possible to use the mod- 
els that represent the S-curves to understand the state or phase in terms of its life cycle or current and future phase in a field of knowledge of research. This becomes an opportunity to apply the methodology of S-curves presented in this paper in other areas of knowledge of interest to research groups, academic programs, doctoral and master's theses in the component of systematic literature review, surveillance and competitive intelligence studies, amongst others.

\section{Limitations and Future Projects}

Cites can be used to evaluate the quality of scientific work, whilst citations have the purpose to measure the obsolescence of a field, in this case, brain drain.

The struggle is in the process of decision making with just one performance parameter. It is suggested that in the subject of brain drain, citations and articles are analyzed simultaneously.

The analysis acquired from the software at the time the inflection point had not occurred, yet estimated in the future(in this case inflection point in 2023)are estimates are shown that should be read carefully now that the software does not have the capacity to allow or read pre-installed limits, threats (legal, political or social). Nonetheless, the fact that the inflection point is in the future shows promise to those interested in publishing topics related to brain drain.

\section{References}

1. Perez C. Cambio tecnologico y oportunidades de desarrol locomoblancomovil. Comision Economica para America Latina y el Caribe. 2001:1-32.

2. Cantu SO, Zapata AR. Quees la gestion de la innovacion y la tecnologia (Ginnt)? Journal of Technology Management and Innovation. 2006 Jun; 1(2):64-82.

3. Brandi M. La historia del brain drain. Revista Iberoamericana de Ciencia Tecnologia y Sociedad. 2006 Sep; 3(7):65-85.

4. Grubel HG. The economics of international labor and capital flows. Economic Aspects of International Migration. Berlin Heidelberg: Springer; 1994. p. 75-92. Crossref

5. Milio S, Lattanzi R, Casadio F, Crosta N, Raviglione M, Ricci P, Scano F. Brain drain brain exchange and brain circula- tion. The Case of Italy Viewed from a Global Perspective. 2012 Mar. p. 1-47.

6. Enciso EMV. Analisis de la Gestion De Tecnologiasemergentes (GTE) engrupo de investigacion colombiano e identificacion de brechas respecto a referents internacionales. Universidad National de Colombia. 2015. p. 1-154.

7. Tidd J, Bessant JR, Pavitt K. Managing innovation: integrating technological, market and organizational change. 5th ed. Chichester: Wiley. 2013. p. 1-602.

8. Aguilar S, Avalos AF, Giraldo DP, Quintero S, Zartha JW, Cortes FB. La Curvaen S comoherramienta para la medicion de los ciclos de vida de productos. Journal of Technology Management and Innovation. 2012.

9. Schilling MA. Strategic Management of Technological Innovation. 4th ed. New York: McGraw Hill; 2013. p. 1-331.

10. Zartha JW, Zuluaga DF, Palacio JC, Montes JM. Ciclo de Vida de Tecnologias y Curvasen S Aplicadasen Subproductos de la Agroindustria Piscicola. Informaciontecnologica. 2017; 28(2):105-14.

11. Afuah AD, Rey D. La dinamica de la innovacionorganizacional: El nuevo concepto para lograrventajas competitivas y rentabilidad. 1999.

12. Perez C. Technological revolutions, paradigm shifts and socio-institutional change. Globalization, Economic Development and Inequality: An Alternative Perspective. 2004; p. 217-42.

13. Kucharavy D, Schenk E, De Guio R. Long-run forecasting of emerging technologies with logistic models and growth of knowledge. 19th CIRP Design Conference; Mar 2009. p. 277.

14. Garfield E. Is citation analysis a legitimate evaluation tool? Scientometrics. 1979 May; 1(4):359-75. Crossref

15. Furner J. Before and after little science big science: A review article Part I. Journal of Librarianship and Information Science. 2003; 35(3). Crossref

16. Lee LC, Lee YY. Bibilometric analysis for discovery of future trends inagricultural technology. The Case of Taiwan. 2013:1-10.

17. Cortes I, Zartha JW, Mendez K, Castrillon F. Valoracion de modelos de curvasen $\mathrm{S}$ aplicadas al sector financierocolombiano. Espacios. 2013; 34(3):2.

18. Lopez CA, Sossa JW, Zarta RH, Reveiz RE, Gomez CA, Uribe JH, Garces JG. Vigilancia Tecnologica y Analisis del Ciclo de Vida de la Tecnologia: Revision de herramientas para el diagnosticoempresarial y la aplicacion del ciclo de vida del productoen el sector turismo. Espacios. 2016. 